\title{
Proteomic analysis of differentially expressed proteins in vitamin C-treated AGS cells
}

\author{
Arulkumar Nagappan ${ }^{1 \dagger}$, Hyeon Soo Park ${ }^{1 \dagger}$, Kwang II Park ${ }^{2}$, Jin A Kim³ ${ }^{3}$ Gyeong Eun Hong ${ }^{1}$, Sang Rim Kang ${ }^{4}$,
} Jue Zhang ${ }^{5}$, Eun Hee Kim ${ }^{6}$, Won Sup Lee ${ }^{7}$, Chung Kil Won ${ }^{1}$ and Gon Sup Kim"

\begin{abstract}
Background: Vitamin C (ascorbic acid) is an essential nutrient of most living tissues that readily acts as a strong reducing agent, which is abundant in fruits and vegetables. Although, it inhibits cell growth in many human cancer cells in vitro, treatment in cancer is still controversial. Hence, the purpose of this study was to investigate the molecular mechanism of the inhibitory effect of vitamin C on AGS cell growth, and protein profiles in AGS cells after exposure to vitamin $C$ treatment, by using proteomic tools.

Results: Vitamin C showed a cytotoxic effect on AGS cells (IC50 $300 \mu \mathrm{g} / \mathrm{mL}$ ) and, 20 differentially expressed proteins (spot intensities which show $\geq 2$ fold change and statistically significant, $p<0.05$ between the control and vitamin-C treated group) were successfully identified by assisted laser desorption/ ionization-time of flight/mass spectrometry (MALDI-TOF/MS). Of the 20 proteins, six were up-regulated and fourteen were down-regulated.

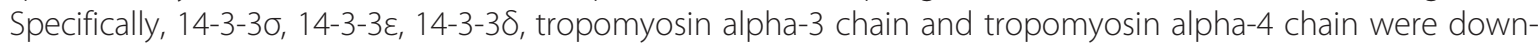
regulated and peroxiredoxin-4 and thioredoxin domain-containing proteins 5 were up-regulated. The identified proteins are mainly involved in cell mobility, antioxidant and detoxification, signal transduction and protein metabolism. Further, the expressions of 14-3-3 isoforms were verified with immuno-blotting analysis.
\end{abstract}

Conclusions: Our proteome results suggest that the apoptosis related proteins were involved in promoting and regulating cell death of AGS cells, and might be helpful to understand the molecular mechanism of vitamin C on AGS cell growth inhibition.

Keywords: Vitamin C, Gastric cancer, AGS cells, Proteome analysis, 14-3-3 isoforms

\section{Background}

Globally, gastric cancer is the second leading cause of cancer-related death, and is the most prevalent cancer in South Korea. In the past two decades, the mortality and incidence of gastric cancer has decreased gradually but it is still the second most common cancer in Asia [1]. Most stomach cancers are an adenocarcinoma type, which accounts approximately 90\% [2]. The well-established risk factors are Helicobacter pylori-infection and cigarette smoking, and the role of dietary factors has also been suggested [3]. The most widely used treatments for stomach cancer are surgery, chemotherapy, and/or radiation therapy.

\footnotetext{
* Correspondence: gonskim@gnu.ac.kr

${ }^{\dagger}$ Equal contributors

'Research Institute of Life Science and College of Veterinary Medicine, Gyeongsang National University, 900 Gajwadong, Jinju, Gyeongnam 660-701, Republic of Korea

Full list of author information is available at the end of the article
}

The available treatments are not effective and recuperation is also still problematic. Hence, there is an urgency to apply new therapeutic agents to increase survival rates of gastric cancer patients.

Vitamin C (ascorbic acid) is an essential nutrient of most living tissues, and readily acts as a strong reducing agent [4]. Epidemiological studies have reported that vitamin $\mathrm{C}$ deficiency in humans are linked to more severe $H$. pylori-associated gastritis and a gastric cancer risk is also higher [5]. The study reported that supplementation of vitamin $C$ has been associated with reduced gastric cancer risk in humans. In addition, a reduced risk for most types of cancer is associated with a high intake of fresh fruits and vegetables, which contain vitamin C [6]. Despite, the controversial cancer treatment history, the in-vitro studies reported that ascorbate induces cell cycle arrest and apoptosis in various tumor cells $[7,8]$. However, the exact

\section{Biomed Central}


mechanism of vitamin $C$ involved in cancer treatment is not fully elucidated.

A global proteomic approach is being extensively applied in cancer research [9]. This approach uses a combination of two-dimensional gel electrophoresis (2-DE), image analysis, matrix-assisted laser desorption/ ionization-time of flight (MALDI-TOF) mass spectrometry (MS), and bioinformatics analyses to comprehensively resolve, identify, and characterize proteins in the cells, tissues and animal models. These high-throughput proteome techniques allow us to examine the changes in protein expression of AGS cells in response to vitamin C. Identification of differentially expressed proteins is important to understand the molecular events involved in vitamin $\mathrm{C}$ anti-cancer mechanism and protective effects, as well as brings new insights into AGS carcinogenesis. Regarding gastric cancer, proteome analysis has been reported mainly in KATO-III and EPG 85-257 human gastric cancer cell lines [10,11]. 2-DE maps have also permitted to obtain an overview of the expressed proteins in the human stomach [12]. Also, proteome analysis has been carried out in 11 human gastric cancer samples to find the biomarkers of gastric cancer [13]. However, no 2-DE proteome of vitamin C-treated AGS cells have hitherto been reported.

Our previous study demonstrated that vitamin $C$ induced apoptosis in human adenocarcinoma AGS cells at pharmacological concentrations, and inhibited AGS cells proliferation [14]. In the present study, we perform a proteome analysis of AGS cells treated with vitamin $C$ at pharmacological concentrations $(300 \mu \mathrm{g})$ and the control (only vehicle), and 20 different expressed proteins were identified by MALDI-TOF/MS. Also, the expression of isoforms of 14-3-3 proteins was confirmed by immunoblotting. The cytotoxicity assay suggests that vitamin $\mathrm{C}$ inhibited AGS cells growth and proteome results revealed that apoptosis related proteins were involved in promoting and regulating cell death of AGS cells.

\section{Methods}

\section{Chemical and reagents}

RPMI 1640 medium was purchased from Hyclone (Logan, UT, USA). Fetal bovine serum (FBS) and antibiotics (streptomycin/penicillin) were purchased from Gibco (BRL Life Technologies, Grand Island, NY, USA). Materials and chemicals used for electrophoresis were obtained from BioRad (Hercules, CA, USA). Antibody to $14-3-3 \sigma$ and $\beta-$ actin were purchased from Millipore (Billerica, MA, USA). $14-3-3 \varepsilon$ and $14-3-3 \delta$ were obtained from Bioworld Technology Inc. (St. Louis Park, MN, USA)). Vitamin C was provided by Animal Resources Research Bank (ABRB). All other chemicals used in this study were purchased from AMRESCO (Solon, OH, USA) and Sigma-Aldrich (St. Louis, MO, USA). All the chemicals used were of the highest grade commercially available.

\section{Cell culture and treatments}

AGS human gastric cancer cell line was purchased from ATCC (Manassas, VA, USA). Cells were grown in RPMI 1640 medium supplemented with $10 \%$ FBS and 1\% penicillin/streptomycin (P-S), and grown in a humidified incubator with $5 \% \mathrm{CO}_{2}$ in air at $37^{\circ} \mathrm{C}$. Experiments were performed when cell growth was approximately $80 \%$ confluent.

\section{Cytotoxicity assay}

The 3-(4, 5-dimethythiazol-2-yl)-2, 5-diphenyltetrazolium bromide (MTT)-based assay was performed to determine the cytotoxicity of vitamin C on AGS cells. Cells were seeded at $10 \times 10^{4}$ cells $/ \mathrm{mL}$ in a 12 -well plate and incubated for $24 \mathrm{~h}$. Cells were treated with various concentrations of vitamin $C(100,200,300,400$, and $500 \mu \mathrm{g} / \mathrm{mL})$ or only vehicle (1X PBS used as the control) and incubated for $24 \mathrm{~h}$. After incubation, $100 \mu \mathrm{l}$ of a MTT solution (5 $\mathrm{mg} / \mathrm{mL}$ in $1 \mathrm{X}$ phosphate buffered saline, PBS) was added to the wells and incubated for $3 \mathrm{~h}$. Then, $500 \mu \mathrm{l}$ of dimethyl sulfoxide (DMSO) was added to each well after the medium was removed completely to dissolve the cellular crystalline deposits. The optical density was measured at $540 \mathrm{~nm}$ using an ELISA plate reader.

\section{Protein extraction and two-dimensional gel electrophoresis}

A total of $1 \times 10^{7}$ cells was plated onto $100 \mathrm{~mL}$ plates and incubated overnight at $37^{\circ} \mathrm{C}$ in an atmosphere of $5 \% \mathrm{CO} 2$. Cells were treated with $300 \mu \mathrm{g} / \mathrm{mL}$ of vitamin $\mathrm{C}$ and $1 \mathrm{X}$ PBS used as the control. After $24 \mathrm{~h}$ incubation, cells were trypsinized and washed twice with cold $1 \mathrm{X}$ PBS. Then, cells were lysed in a lysis buffer (7 M urea, $2 \mathrm{M}$ thiourea, and $4 \%(\mathrm{w} / \mathrm{v}) \mathrm{CHAPS})$ on ice for $1 \mathrm{~h}$. The lysates were centrifuged at $14000 \mathrm{rpm}$ for $15 \mathrm{~min}$ at $4^{\circ} \mathrm{C}$, and the collected supernatant was stored at $-80^{\circ} \mathrm{C}$ until analysis. Proteins in lysates were precipitated with equal volume (1:1) of $20 \% \mathrm{v} / \mathrm{v}$ trichloroacetic acid and dissolved in $7 \mathrm{M}$ urea, $2 \mathrm{M}$ thiourea, and 4\% (w/v) CHAPS, 0.5\% (v/v) IPG buffer, and $1 \%$ dithiothreitol (DTT). Protein concentration was determined by the Non-Interfering ${ }^{\mathrm{TM}}$ protein assay kit (GBiosciences, St. Louis, MO, USA), in accordance to the manufacturer's protocol. Immobilized $18 \mathrm{~cm}$ linear $\mathrm{pH}$ gradient (IPG) strips, pH 4-7, were rehydrated in a rehydration buffer (7 M urea, $2 \mathrm{M}$ thiourea, $4 \%$ (w/v) CHAPS, 0.002\% Bromophenol blue). For the first dimension, $100 \mu \mathrm{g}$ protein was focused using the Ettan IPG Phor II (GE Healthcare) at $50 \mathrm{~V}$ for $1 \mathrm{~h}$, followed by $200 \mathrm{~V}$ for $1 \mathrm{~h}$, $500 \mathrm{~V}$ for $30 \mathrm{~min}, 4000 \mathrm{~V}$ for $30 \mathrm{~min}, 4000 \mathrm{~V}$ for $1 \mathrm{~h}$, $10000 \mathrm{~V}$ for $1 \mathrm{~h}, 10000 \mathrm{~V}$ for $13 \mathrm{~h}$, and $50 \mathrm{~V}$ for $3 \mathrm{~h}$. The focused strips were equilibrated twice, $15 \mathrm{~min}$ each time, first with $10 \mathrm{mg} / \mathrm{mL}$ DTT and then with $40 \mathrm{mg} / \mathrm{mL}$ iodoacetamide (IAA) prepared in equilibration buffer containing $50 \mathrm{mM}$ Tris- $\mathrm{HCl}(\mathrm{pH} 8.8), 6 \mathrm{M}$ urea, 30\% (v/v) 
glycerol, 2\% (w/v) SDS, and 0.002\% (w/v) Bromophenol blue. The focused proteins were then separated in the second dimension by $12 \%$ linear gradient SDS-PAGE with a constant current of $20 \mathrm{~mA} / \mathrm{gel}$ at $20^{\circ} \mathrm{C}$. Gels were run until the Bromophenol dye front reached the end of the gel.

\section{Protein detection, analysis, and in-gel digestion}

The gels were stained with silver nitrate, similar to the method described by Swain and Ross [15] with slight modifications. Three independent gels were performed in triplicate. Gels were scanned and image analysis was performed, using Progenesis Samespots software (Nonlinear Dynamics, Newcastle, UK). Using this software, the differentially expressed spots were identified by automatic matching of the detected protein spots. Those spots differing significantly $(\mathrm{p}<0.05)$ in their intensities with a fold-change $\geq 2$ were used for further analysis. Selected protein spots were excised manually from the two-dimensional electrophoresis (2-DE) gel and protein digestion was performed [16] with slight modifications. Briefly, the excised gel pieces were washed with $100 \mu \mathrm{l}$ of $100 \mathrm{mM} \mathrm{NH}_{4} \mathrm{HCO}_{3}$ for $5 \mathrm{~min}$, and then dehydrated in $100 \mu \mathrm{l}$ of acetonitrile for $10 \mathrm{~min}$. After being dried in a lyophilizer (SFDSM06, Samwon Freezing Engineering Co., Busan), the gel pieces were rehydrated in $5-10 \mu \mathrm{l}$ of $50 \mathrm{mM} \mathrm{NH} \mathrm{HCO}_{3}$ containing $20 \mathrm{ng} / \mu \mathrm{l}$ trypsin (Promega, Madison, WI, USA) on ice. After $45 \mathrm{~min}$, the trypsin solution was removed and replaced with $10-20 \mu \mathrm{l}$ of $50 \mathrm{mM} \mathrm{NH}_{4} \mathrm{HCO}_{3}$ without trypsin, and digestion was carried out for a minimum of $16 \mathrm{~h}$ at $37^{\circ} \mathrm{C}$. These peptide mixtures were collected and analyzed by a mass spectrometry.

\section{Matrix-assisted laser desorption/ionization-time of flight mass spectrometry (MALDI-TOF MS) mass spectrometry and database searching}

Tryptic peptides obtained as described above were subsequently extracted by an addition of $10 \mu \mathrm{l}$ of the extraction buffer, followed by an addition of 10-15 $\mu \mathrm{l}$ of acetonitrile. Pooled extracts were dried in a lyophilizer (SFDSM06, Samwon Freezing Engineering Co., Busan) and the extracts were re-dissolved in $1 \mu \mathrm{l}$ of extraction buffer and $1 \mu \mathrm{l}$ of matrix solution ( $\alpha$-acyano- 4-hydroxycinnamic acid, HCCA) and targeted onto a MALDI-TOF plate. After drying the samples completely onto the targeting plate, MALDI-TOF/MS was conducted using a Voyager- DE STR mass spectrometer (Applied Biosystems, Franklin Lakes, NJ, USA) equipped with delay ion extraction. Mass spectra were obtained over a mass range of 800-3,000 Da. For identification of proteins, the peptide mass fingerprinting data were used to search against the Swissprot database using the Mascot program (http://www.matrixscience.com). The following parameters were used for database searches: taxonomy, Homo sapiens (human); cleavage specificity, trypsin with one missed cleavage allowed; peptide tolerance of 100 ppm for the fragment ions; and allowed modifications, Cys Carbamidomethyl (fixed), and oxidation of Met (variable). Protein scores $>56$ were considered statistically significant $(p<0.05)$.

\section{Western blot analysis}

AGS cells were cultured in 6-well plates and incubated with vitamin $\mathrm{C}$ at $300 \mu \mathrm{g} / \mathrm{mL}$ or PBS as the solvent control for $24 \mathrm{~h}$. After incubation, cells were washed with ice-cold PBS and lysed with a lysis buffer [50 mM Tris- $\mathrm{HCl}(\mathrm{pH}$ 8.0), $150 \mathrm{mM} \mathrm{NaCl}, 0.5 \%$ sodium deoxycholate, $0.1 \%$ sodium dodecyl sulfate (SDS) and 1\% NP-40], containing the protease inhibitor cocktail. The cell debris was removed by centrifugation at 13,000 rpm for $30 \mathrm{~min}$ and protein concentration was determined using a Bradford assay (BioRad). Proteins were separated by $10 \%$ SDS-polyacrylamide gel electrophoresis (SDS-PAGE) and transferred to a polyvinyldene fluoride (PVDF) membrane (ImmunobilonP, $0.45 \mathrm{~mm}$; Millipore) using the TE 77 Semi-Dry Transfer Unit (CE Healthcare Life Sciences, Buckinghamshire, UK). The membrane was blocked with $5 \%$ non-fat skim milk in Tris-buffered saline containing 1\% Tween-20 (TBS, pH 7.4) at room temperature for $1 \mathrm{~h}$, and the blots were probed with rabbit monoclonal antibody to 14-3-30, 14-3$3 \varepsilon$ and $14-3-3 \delta$, and mouse monoclonal antibody for $\beta$ actin. The proteins were visualized using an enhanced chemiluminescence kit (ECL) and Western blotting detection reagents (GE Healthcare Life Sciences), and exposed to X-ray film (Fuji, Tokyo, Japan). Each band was quantitatively determined using Image J (http://rsb.info.nih.gov) software. The densitometry readings of the bands were normalized to $\beta$-actin expression.

\section{Statistical analysis}

The data represents the mean \pm standard deviation (SD) of three independent experiments. The statistical significance between the control and sample groups was calculated by the Student's t-test. A $p$ value $<0.05$ was considered as significant.

\section{Results}

\section{Growth inhibition of AGS cells by vitamin C}

To evaluate the effects of growth inhibition and survival of AGS cells, the AGS cells were cultured in the presence of various concentrations $(0-500 \mu \mathrm{g} / \mathrm{mL})$ of vitamin C for $24 \mathrm{~h}$. Vitamin C had a strong inhibitory effect on cell proliferation of AGS cells in a dose-dependent manner when compared to the control, after $24 \mathrm{~h}$ treatment with vitamin $\mathrm{C}$ (Figure 1A). Especially, vitamin $\mathrm{C}$ at 300,400 and $500 \mu \mathrm{g} / \mathrm{mL}$ decreased the cell growth by approximately $50 \%, 36 \%$ and $27 \%$, respectively. Therefore, the IC50 (50\% inhibitory concentration) of vitamin $C$ was found to be approximately $300 \mu \mathrm{g} / \mathrm{mL}$. Moreover, microscopic observations revealed morphological 


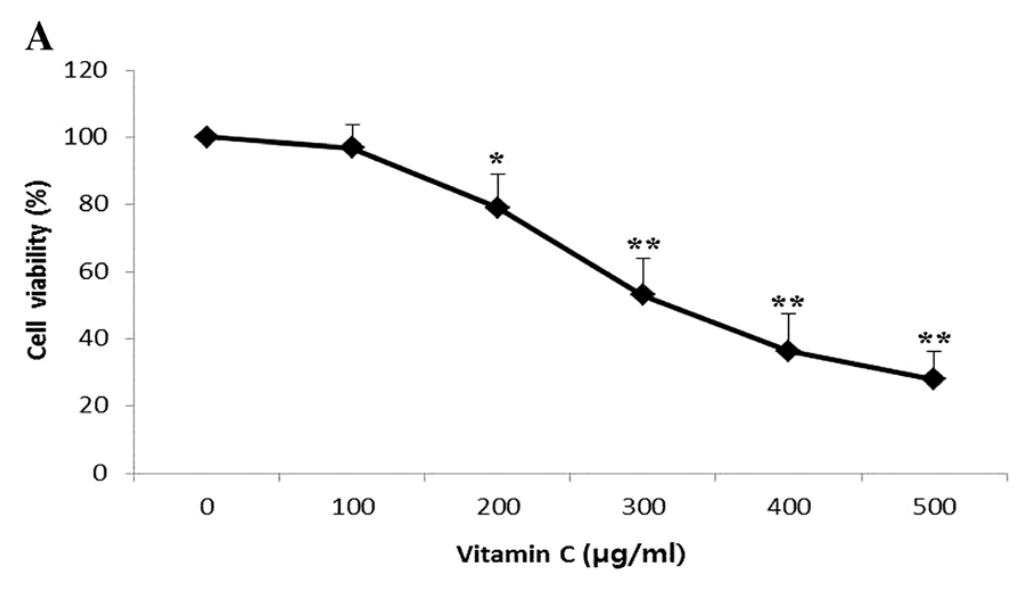

B

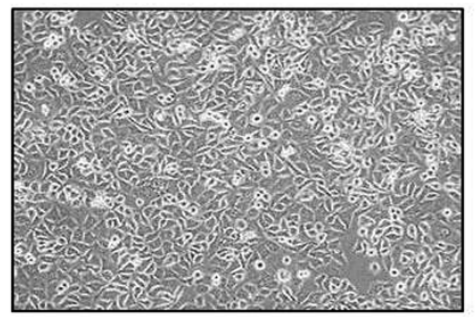

$0 \mu \mathrm{g} / \mathrm{ml}$

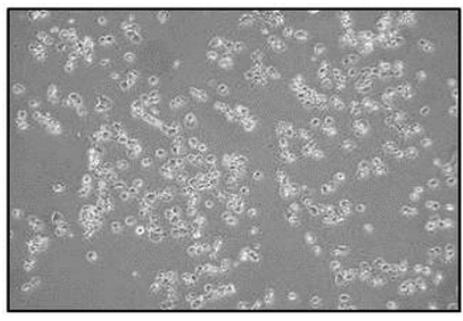

$300 \mu \mathrm{g} / \mathrm{ml}$

Figure 1 Effects of vitamin C on cell viability on AGS adenocarcinoma gastric cancer cell line. (A) The cells were exposed to vitamin C at the indicated dosages for $24 \mathrm{~h}$ and cell viability was determined. Vehicle-treated cells were arbitrarily set as $100 \%$ control viability. (B) Morphology of AGS cells treated with or without vitamin C for $24 \mathrm{~h}$ and examined by light microscopy (400). Results are expressed as the mean \pm SD of three independent experiments $\left({ }^{*} \mathrm{P}<0.05 ;{ }^{* *} \mathrm{P}<0.01\right.$, compared to control).

changes in AGS cells, such as cell shrinkage and density compared with the control cells (Figure 1B). Further, 2-DE gel analysis was performed to study the protein expressions in AGS cells due to inhibitory effects of vitamin $\mathrm{C}$.

\section{Proteomic analysis to identify differentially expressed proteins in vitamin C-treated AGS cells}

We performed a proteomic approach to identify proteins that were differentially expressed in vitamin $\mathrm{C}$ treated $(300 \mu \mathrm{g} / \mathrm{mL})$ AGS cells, $100 \mu \mathrm{g}$ of total proteins were separated by IEF on $18 \mathrm{~cm}$ IPG strips in the first dimension and $12 \%$ SDS-PAGE in the second dimension. We observed a total of approximately 500 protein spots in silver stained gels. Control (only vehicle) and vitamin $C$ treated gels were analyzed by using Progenesis Samespots software (Nonlinear Dynamics, Newcastle, UK), and we found 32 statistically significant differentially expressed protein spots ( $\geq 2$-fold and $\mathrm{p}<0.05$ ). These 32 differentially expressed proteins spots were chosen for further analysis by MALDITOF/MS. Finally, 20 differentially expressed proteins were successfully identified by using the MASCOT search engine and the SwissProt database (Figure 2 and Table 1).
Of these 20 proteins, six were up-regulated and fourteen were down-regulated in vitamin C-treated AGS cells compared with the control. Down-regulated proteins involved in cell motility included tropomyosin alpha-3 chain (TPM3) and tropomyosin alpha-4 chain (TPM4), whereas Xin actin-binding repeat-containing protein 1 (XIRP1) was up-regulated. In addition, the peroxiredoxin-4 (PRDX4) and thioredoxin domain-containing protein 5 (TXND5) were involved in antioxidant and detoxification, which was up-regulated. While proteins participating in signal transduction were significantly down-regulated, including 14-3-3 protein sigma (SFN), 14-3-3 protein epsilon (YWHAE) and 14-3-3 protein zeta/delta (YWHAZ), whereas TNFAIP3-interacting protein 2 (TNIP2) was upregulated. Proteins involved in protein metabolism Eukaryotic translation initiation factor 3 subunit K (EIF3K), Proteasome subunit alpha type-5 (PSMA5) and Proteasome subunit beta type-6 (PSMB6) were down-regulated. Further, we showed the enlarged 2-DE images of 6 important protein spots, one spot (Peroxiredoxin-4) was upregulated and the other five $(14-3-3 \sigma, 14-3-3 \varepsilon, 14-3-3 \delta$, tropomyosin alpha-3 chain and tropomyosin alpha-4 chain) were down-regulated in the vitamin C-treated AGS cells compared with the control (Figure 3). 


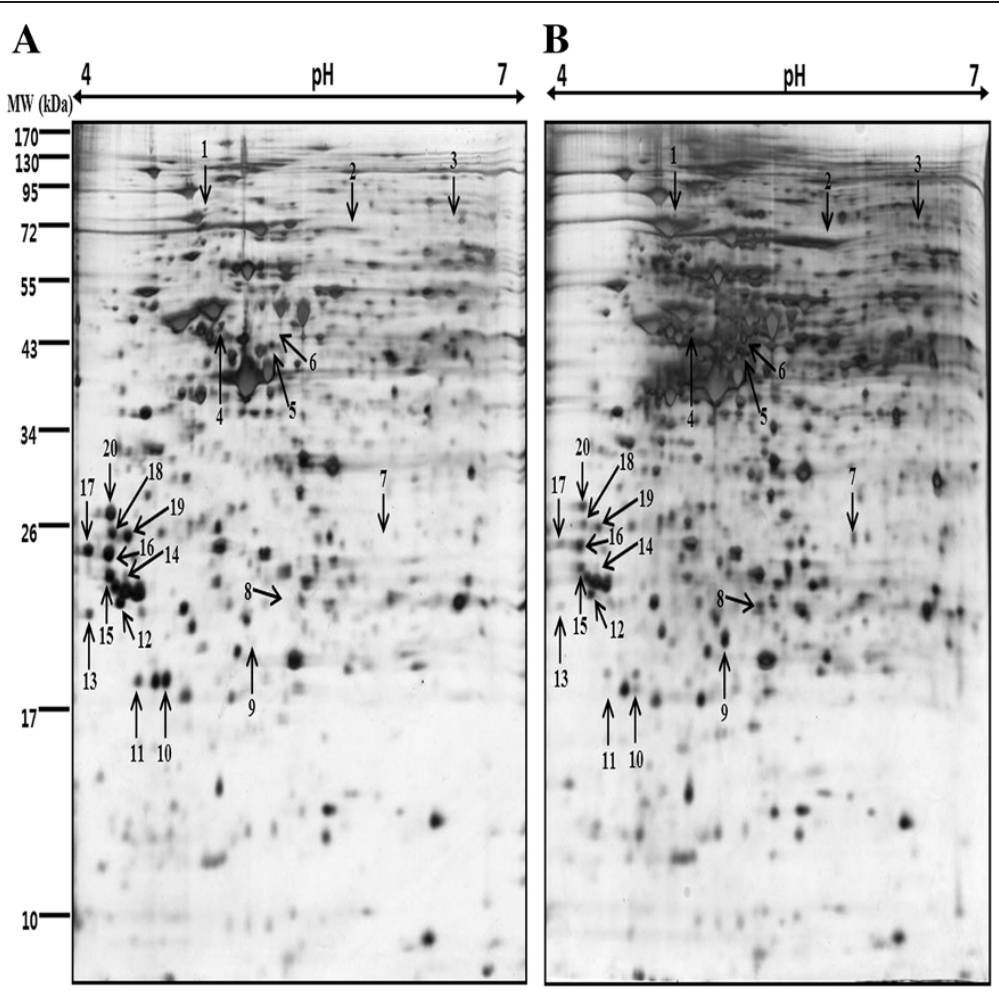

Figure 2 Two-dimensional map of proteins from AGS gastric cancer cells treated with vitamin C. Proteins were isolated after exposure of the cells to $\mathbf{A}$ ) control (only vehicle) and B) $300 \mu \mathrm{g} / \mathrm{ml}$ of vitamin C for $24 \mathrm{~h}$ and separated on IPG-strips with pH 4-7 in the first dimension, and then on $12 \%$ polyacrylamide gel on second dimension. The gels were silver stained.

\section{Validation of expression of 14-3-3 isoforms by immunoblotting}

Recent research on cancer targets have focused 14-3-3 proteins that are known to be involved in various biological processes like signal transduction, cell cycle control, apoptosis, cellular metabolism, proliferation, cytoskeletal regulation, transcription, and redox-regulation or stress response. The AGS cells were treated with vitamin $C(0$, and $300 \mu \mathrm{g} /$ $\mathrm{mL}$ ) and the expression of $14-3-3 \sigma, 14-3-3 \varepsilon$ and $14-3-3 \delta$ were examined by immuno-blotting. Quantification of the protein bands revealed that the expression of $14-3-3 \sigma, 14-$ $3-3 \varepsilon$ and $14-3-3 \delta$ were decreased in the vitamin C-treated group compared to the vehicle-treated control group (Figure 4). These data indicated that vitamin $\mathrm{C}$ decreased

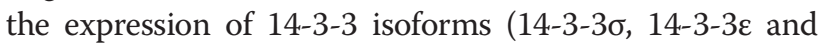
14-3-38) in AGS cells.

\section{Discussion}

Apart from antioxidant activity, vitamin $C$ plays an effective role of cancer prevention and treatment. The numerous studies have reported that vitamin $\mathrm{C}$ prevents cell proliferation and metastasis of many human cancer cells [17-19]. But, it's exact molecular mechanisms still has not been fully elucidated. In the previous study, we demonstrated that vitamin $C$ at pharmacological concentration induced apoptosis in AGS cells, mainly through the down-regulation of
14-3-3 $\sigma$ protein and dephosphorylation Bad proteins via a mitochondrial dependent pathway [14]. In the present study, we performed 2-DE analysis coupled with MALDITOF/MS of AGS cells treated with vitamin $\mathrm{C}$ at a pharmacological concentration $(300 \mu \mathrm{g} / \mathrm{mL})$ and the control (only vehicle), and 20 differentially expressed proteins were identified. Proteomic analysis revealed that the apoptosis related proteins were involved in promoting and regulating cell death of AGS cells.

Ascorbic acid is an excellent antioxidant and ascorbate caused toxicity to cancer cells, but had no effect on normal cells at the same concentration [20]. In the present study, vitamin $C$ had a strong inhibitory effect on cell proliferation of AGS cells in a dose-dependent manner after $24 \mathrm{~h}$ treatment with vitamin $\mathrm{C}$ (Figure $1 \mathrm{~A}$ ), and the IC50 of vitamin $\mathrm{C}$ was found approximately $300 \mu \mathrm{g} / \mathrm{mL}$ or 1.7 $\mathrm{mM} / \mathrm{mL}$. And also, morphological changes were observed in AGS cells, such as cell shrinkage and density in vitamin $\mathrm{C}$ treated cells compared with the control cells (Figure 1B). This result revealed that vitamin $C$ inhibited AGS cell growth at pharmacological concentrations. Further, 2-DE gel analysis was performed to study the protein expressions in AGS cells due to inhibitory effects of vitamin C. The silver stained gels of control (only vehicle) and vitamin $C$ treated gels were analyzed by using Progenesis Samespots software (Nonlinear Dynamics, Newcastle, 
Table 1 Differentially expressed proteins in Vitamin C treated AGS cells identified by MALDI-TOF/MS

\begin{tabular}{|c|c|c|c|c|c|c|c|c|}
\hline $\begin{array}{l}\text { Spot } \\
\text { no. }\end{array}$ & $\begin{array}{l}\text { Swissprot } \\
\text { entry name }\end{array}$ & Protein name $^{1}$ & $\begin{array}{l}\text { Accession } \\
\text { number }^{1}\end{array}$ & $\begin{array}{c}\text { Theoretical/ } \\
\text { experimental } \\
\mathrm{Mr}^{(\mathrm{kDa})^{2}}\end{array}$ & $\begin{array}{l}\text { Theoretical/ } \\
\text { experimental } \\
\text { pl value }\end{array}$ & $\begin{array}{l}\text { Protein } \\
\text { score }^{3}\end{array}$ & $\begin{array}{c}\text { Sequence coverage } \\
\text { (\%)/peptides } \\
\text { matched }\end{array}$ & $\begin{array}{l}\text { Fold } \\
\text { change }\end{array}$ \\
\hline \multicolumn{9}{|c|}{ Up - regulated proteins } \\
\hline 2 & TNIP2_HUMAN & $\begin{array}{l}\text { TNFAIP3-interacting } \\
\text { protein } 2\end{array}$ & Q8NFZ5 & $49.24 / 91$ & $6.03 / 5.83$ & 56 & $15 / 7$ & 2.3 \\
\hline 3 & XIRP1_HUMAN & $\begin{array}{l}\text { Xin actin-binding } \\
\text { repeat-containing } \\
\text { protein } 1\end{array}$ & Q702N8 & $199.64 / 96$ & $5.78 / 6.48$ & 59 & $11 / 13$ & 2.2 \\
\hline 6 & TXND5_HUMAN & $\begin{array}{l}\text { Thioredoxin domain- } \\
\text { containing protein } 5\end{array}$ & Q8NBS9 & $48.28 / 49$ & $5.63 / 5.38$ & 81 & $22 / 10$ & 2.9 \\
\hline 7 & CE290_HUMAN & $\begin{array}{c}\text { Centrosomal protein of } \\
290 \mathrm{kDa}\end{array}$ & 015078 & $290.89 / 28$ & $5.75 / 6.04$ & 69 & $9 / 16$ & 8.5 \\
\hline 8 & PRDX4_HUMAN & Peroxiredoxin-4 & Q13162 & $30.75 / 24$ & $5.86 / 5.43$ & 68 & $38 / 6$ & 3.0 \\
\hline 9 & CE290_HUMAN & $\begin{array}{c}\text { Centrosomal protein of } \\
290 \mathrm{kDa}\end{array}$ & O15078 & $290.89 / 23$ & $5.75 / 5.21$ & 60 & $8 / 15$ & 6.4 \\
\hline \multicolumn{9}{|c|}{ Down - regulated proteins } \\
\hline 1 & DPP3_HUMAN & Dipeptidyl peptidase 3 & Q9NY33 & $82.88 / 100$ & $5.02 / 4.86$ & 110 & $26 / 12$ & 4.0 \\
\hline 4 & DCTN2_HUMAN & Dynactin subunit 2 & Q13561 & $44.32 / 51$ & $5.10 / 4.94$ & 122 & $39 / 13$ & 2.3 \\
\hline 5 & IF4A1_HUMAN & $\begin{array}{l}\text { Eukaryotic initiation } \\
\text { factor } 4 \mathrm{~A}-1\end{array}$ & P60842 & $46.35 / 48$ & $5.32 / 5.31$ & 175 & $47 / 17$ & 2.1 \\
\hline 10 & PSB6_HUMAN & $\begin{array}{l}\text { Proteasome subunit } \\
\text { beta type- } 6\end{array}$ & PSMB6 & $25.57 / 21$ & $4.80 / 4.64$ & 104 & $39 / 10$ & 4.4 \\
\hline 11 & EIF3K_HUMAN & $\begin{array}{c}\text { Eukaryotic translation } \\
\text { initiation factor } 3 \\
\text { subunit K }\end{array}$ & Q9UBQ5 & $25.33 / 21$ & $4.81 / 4.46$ & 101 & $37 / 8$ & 3.6 \\
\hline 12 & PSA5_HUMAN & $\begin{array}{l}\text { Proteasome subunit } \\
\text { alpha type- } 5\end{array}$ & P28066 & $26.57 / 24$ & $4.74 / 4.31$ & 91 & $41 / 8$ & 2.0 \\
\hline 13 & IFG_HUMAN & $\begin{array}{l}\text { Eukaryotic translation } \\
\text { initiation factor } 6\end{array}$ & P56537 & $27.10 / 23$ & $4.56 / 4.13$ & 86 & $50 / 7$ & 3.8 \\
\hline 14 & 1433Z_HUMAN & $\begin{array}{l}\text { 14-3-3 protein zeta/ } \\
\text { delta }\end{array}$ & P63104 & $27.9 / 25$ & $4.73 / 4.36$ & 93 & $40 / 10$ & 2.6 \\
\hline 15 & 1433S_HUMAN & 14-3-3 protein sigma & P31947 & $27.87 / 25$ & $4.68 / 4.26$ & 150 & $58 / 12$ & 2.2 \\
\hline 16 & 1433E_HUMAN & 14-3-3 protein epsilon & P62258 & $29.33 / 26$ & $4.63 / 4.27$ & 131 & $93 / 12$ & 2.3 \\
\hline 17 & EF1B_HUMAN & Elongation factor 1-beta & P24534 & $24.92 / 26$ & $4.50 / 4.12$ & 130 & $50 / 11$ & 3.3 \\
\hline 18 & TPM4_HUMAN & $\begin{array}{l}\text { Tropomyosin alpha- } 4 \\
\text { chain }\end{array}$ & P67936 & $28.62 / 27$ & $4.67 / 4.28$ & 94 & $25 / 10$ & 3.1 \\
\hline 19 & TPM3_HUMAN & $\begin{array}{l}\text { Tropomyosin alpha-3 } \\
\text { chain }\end{array}$ & P06753 & $32.86 / 27$ & $4.68 / 4.37$ & 95 & 20/11 & 2.7 \\
\hline 20 & PCNA_HUMAN & $\begin{array}{c}\text { Proliferating cell nuclear } \\
\text { antigen }\end{array}$ & P12004 & $29.09 / 29$ & $4.57 / 4.28$ & 127 & $40 / 10$ & 2.5 \\
\hline
\end{tabular}

${ }^{1}$ Entry name, protein name and accession number from SWISS-PROT database identified by MALDI-TOF/MS.

${ }^{2}$ Theoretical molecular weight $(\mathrm{kDa})$ and pl from SWISS-PROT database; the experimental values of pl and MW for every isoelectric spot were calculated using Progenesis samespots software (Nonlinear Dynamics Ltd., Newcastle, UK).

${ }^{3}$ Score is $-10 * \log (p)$, where $p$ is the probability that the observed match is a random event, Protein scores greater than 56 are significant $(p<0.05)$.

UK), and we found 32 statistically significant differentially expressed protein spots $(\geq 2$-fold and $\mathrm{p}<0.05)$. Finally, 20 differentially expressed proteins were successfully identified by MALDI-TOF/MS analysis using the MASCOT search engine and the SwissProt database (Figure 2 and Table 1). Among 20 proteins, six were up-regulated and fourteen were down-regulated in vitamin C-treated AGS cells compared with the control. These proteins are mainly involved in cell mobility, antioxidant and detoxification, signal transduction and protein metabolism.

Vitamin C down-regulated proteins involved in the signal transduction, 14-3-3 isoforms

Research on cancer targets have determined that 14-3-3 proteins are known to be involved in various biological processes like signal transduction, cell cycle control, 


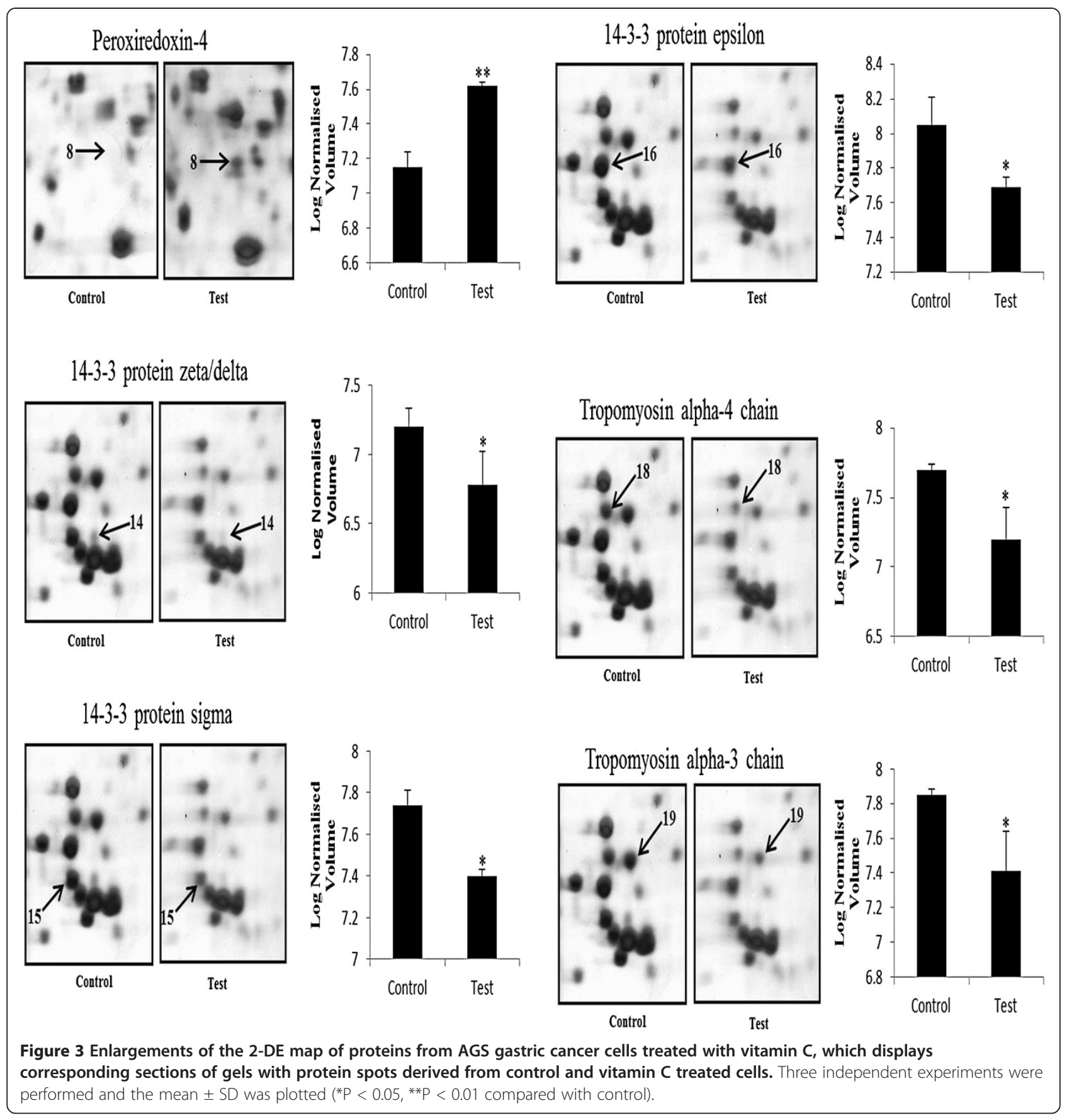

apoptosis, cellular metabolism, proliferation, cytoskeletal regulation, transcription, and redox-regulation or stress response [21]. Among these differentially expressed proteins, three isoforms of 14-3-3 proteins, 14-3-3 $\sigma$ and 14-3$3 \varepsilon$ and $14-3-3 \delta$ were down-regulated (Figure 2). The Bad protein, a proapoptotic family member, is one of the targets of 14-3-3 proteins [22]. When Bad disassociated from 14-3-3, the Bad is found localized to the mitochondria bound to $\mathrm{Bcl}-2$ and $\mathrm{Bcl}-\mathrm{xL}$, and induced cell death $[23,24]$. In addition, vitamin $C$ induced apoptosis by down-regulation of $14-3-3 \sigma$ and dephosphorylation of Bad via a mitochondrial dependent pathway in AGS cells [14]. Moreover, the remarkable dissociation of Bad from $14-3-3 \beta$ is the apoptosis mechanism of vitamin $C$ through the increasing of ER stress and the translocation of Bad to mitochondria after dissociation from $14-3-3 \beta$ in human colon cancer cell line, HCT-8 [25]. These findings suggest that Bad dissociated from 14-3-3 is a key mediator in vitamin C-induced apoptosis through the disruption of mitochondrial membrane potential. 


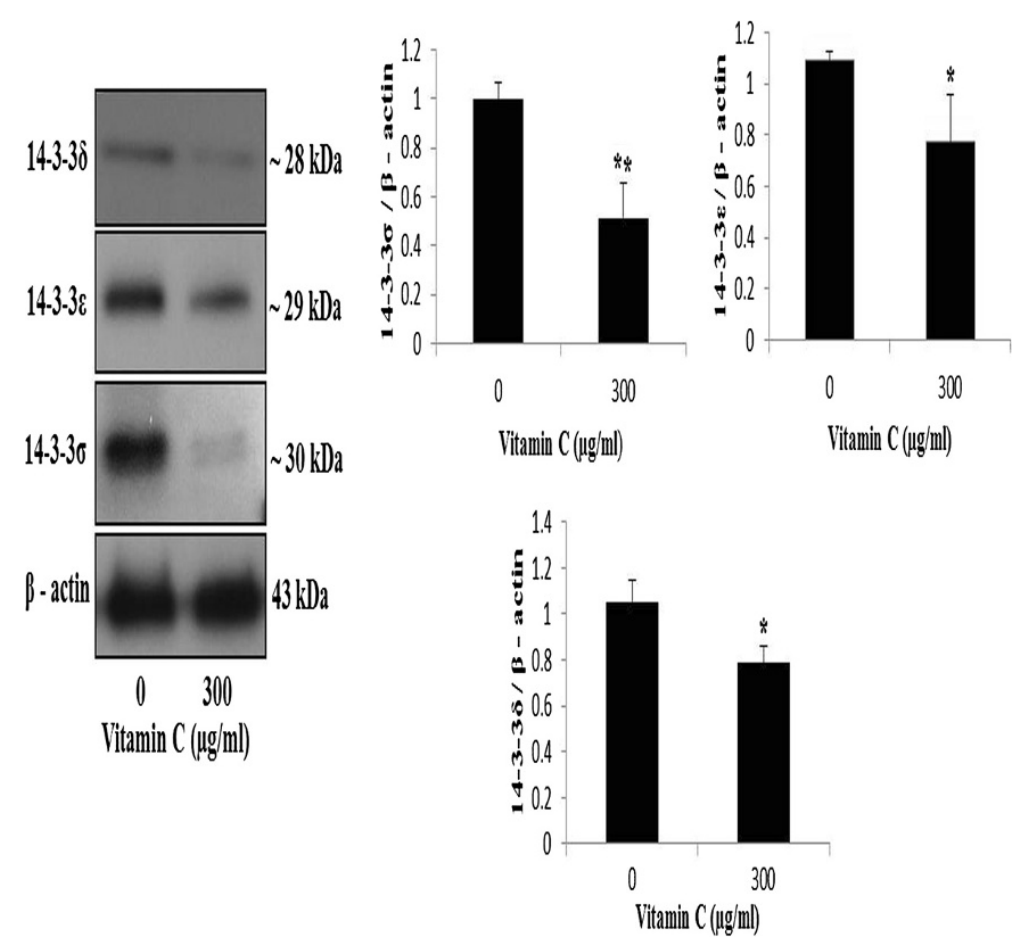

Figure 4 Effects of vitamin C on expression of 14-3-3 isoforms in AGS cells. Cells were treated with vitamin C (0 and $300 \mathrm{lg} / \mathrm{ml})$ for $24 \mathrm{~h}$. The cell lysates were subjected to SDS-PAGE and analyzed by Western blotting. Densitometric analyses of data were expressed as the mean \pm SD of three independent experiments ( ${ }^{*} P<0.05,{ }^{* *} P<0.01$ compared with control).

The down-regulation of $14-3-3 \sigma$ protein has been reported in many types of cancer, including breast cancer [26], and expression is frequently lost in other human epithelial carcinomas [27]. Moreover, other 14-3-3e, $\zeta, \gamma, \beta, \theta$ isoforms have also been identified in cancer [28]. After DNA-damage, 14-3-3 $\sigma$ down-regulated cells fail to maintain a G2/M arrest and undergo a mitotic catastrophe, which results in apoptosis [29]. The reduction of 14-3-3 expression induced the G2 arrest, which leads to mitotic catastrophe and increase radio sensitivity [30]. To verify the expressions of identified proteins, we performed an immuno-blotting

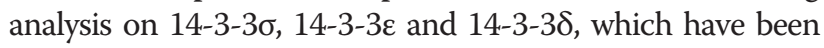
suggested to be involved in various cancers. Quantification of the protein bands determined that the expression of 14$3-3 \sigma, 14-3-3 \varepsilon$ and $14-3-3 \delta$ were decreased in the vitamin C-treated group compared to the vehicle-treated control group (Figure 4). These data indicated that vitamin $\mathrm{C}$ decreased the expression of 14-3-3 isoforms (14-3-36, 14-3$3 \varepsilon$ and 14-3-38) in AGS cells. These data suggest that down-regulation of 14-3-3 could be a useful information in therapeutic targets of human gastric cancers.

Vitamin C down-regulated the cytoskeleton and associated proteins, tropomyosin alpha-3 chain and tropomyosin alpha- 4 chain proteins

Tropomyosins are actin-binding proteins that can integrate cell mechanics and signaling essential for cellular migration and invasion. Proteomic studies showed that the expression of tropomyosin changes, which suggest an important role for tropomyosin in maintaining cell shape [31]. In addition, tropomyosins increase filament stiffness, stabilize actin filaments by protecting them against the severing action of gelsolin and cofilin [32]. In our $2 \mathrm{D}$ gel system, the spots corresponding to tropomyosin 3 and tropomyosin 4 showed a decreased expression in the response to vitamin $\mathrm{C}$ (Figure 3). These decreased changes in the tropomyosins expression might be coincidental with morphologic changes and migratory characteristics of AGS cells in response to vitamin C.

\section{Vitamin C up-regulated the antioxidant proteins, peroxiredoxin-4 and thioredoxin domain-containing protein 5}

Generally, antioxidant proteins play a pivotal role in the antioxidant defense system and protect the cells from oxidative stress. There are six peroxiredoxins found in mammalians, and peroxiredoxin 4 (PRDX4) is localized in the endoplasmic reticulum (ER) [33]. In the present study, antioxidant and detoxification proteins, like peroxiredoxin4 and thioredoxin domain-containing protein 5 , were over expressed in vitamin C treated AGS cells (Figure 3). Since, vitamin $C$ is an excellent antioxidant that increased antioxidant protein expressions in AGS cells and protects from oxidative stress. To our knowledge there has not been a 
reported study regarding peroxiredoxin-4 protein expression in human gastric cancer adenocarcinoma AGS cells response to vitamin $\mathrm{C}$. Therefore, a detailed study is necessary regarding the effects of vitamin $C$ on peroxiredoxin-4 protein expressions and the role of peroxiredoxin- 4 protein in tumorigenesis of gastric cancer.

\section{Vitamin C altered the proteins involved in protein metabolism}

Also, we found that EIF3K was down-regulated in vitamin C-treated AGS cells. A previous study has been reported that the down-regulation of eIF3k attenuating apoptosis in simple epithelial cells [34]. Tumor Necrosis Factor (TNF) Alpha-Induced Protein 3 (also known as A20-binding inhibitor of NF-kappa-B activation 2) or TNFAIP3 is a novel tumor suppressor protein and a key player in the negative feedback regulation of NF-kB signaling in response to multiple stimuli. TNFAIP3 also regulates TNF-induced apoptosis [35]. Moreover, TNFAIP3 induces cell growth arrest and apoptosis, accompanied by down-regulation of nuclear factor-kappa B (NF-kB) activation [36,37]. Presently, TNFAIP3 was up-regulated in vitamin $\mathrm{C}$ treated AGS cells. Figure 5 represents the overview of the growth inhibition effect of vitamin C on AGS cells and protein expression patterns. These proteomic results reveal that vitamin $\mathrm{C}$ inhibited cell growth, and apoptosis related proteins were involved in promoting and regulating cell death in AGS cells.

\section{Conclusions}

In summary, vitamin $\mathrm{C}$ showed strong inhibitory effect on AGS cell growth at pharmacological concentrations $(300 \mu \mathrm{g} / \mathrm{mL})$, and 20 differentially expressed proteins were identified in AGS cells after exposure to vitamin C by using 2-DE and MADLI-TOF analysis. In particular, proteins involved in signal transduction 14-3-3 $\sigma, 14-3-$ $3 \varepsilon$ and $14-3-3 \delta$, and cytoskeletal proteins tropomyosin alpha-3 chain and tropomyosin alpha-4 chain were down-regulated; Peroxiredoxin-4 was up-regulated in vitamin C-treated AGS cells compared with the control. Further, the expressions of 14-3-3 isoforms (14-3-3 $\sigma$, $14-3-3 \varepsilon$ and $14-3-3 \delta$ ) were verified with a Western blot analysis. The findings of this study suggest that vitamin C could inhibit AGS cell growth, alter the apoptosis related proteins, and might be helpful to understand the molecular mechanism of vitamin $C$ 's anti-tumor effect in AGS cells.

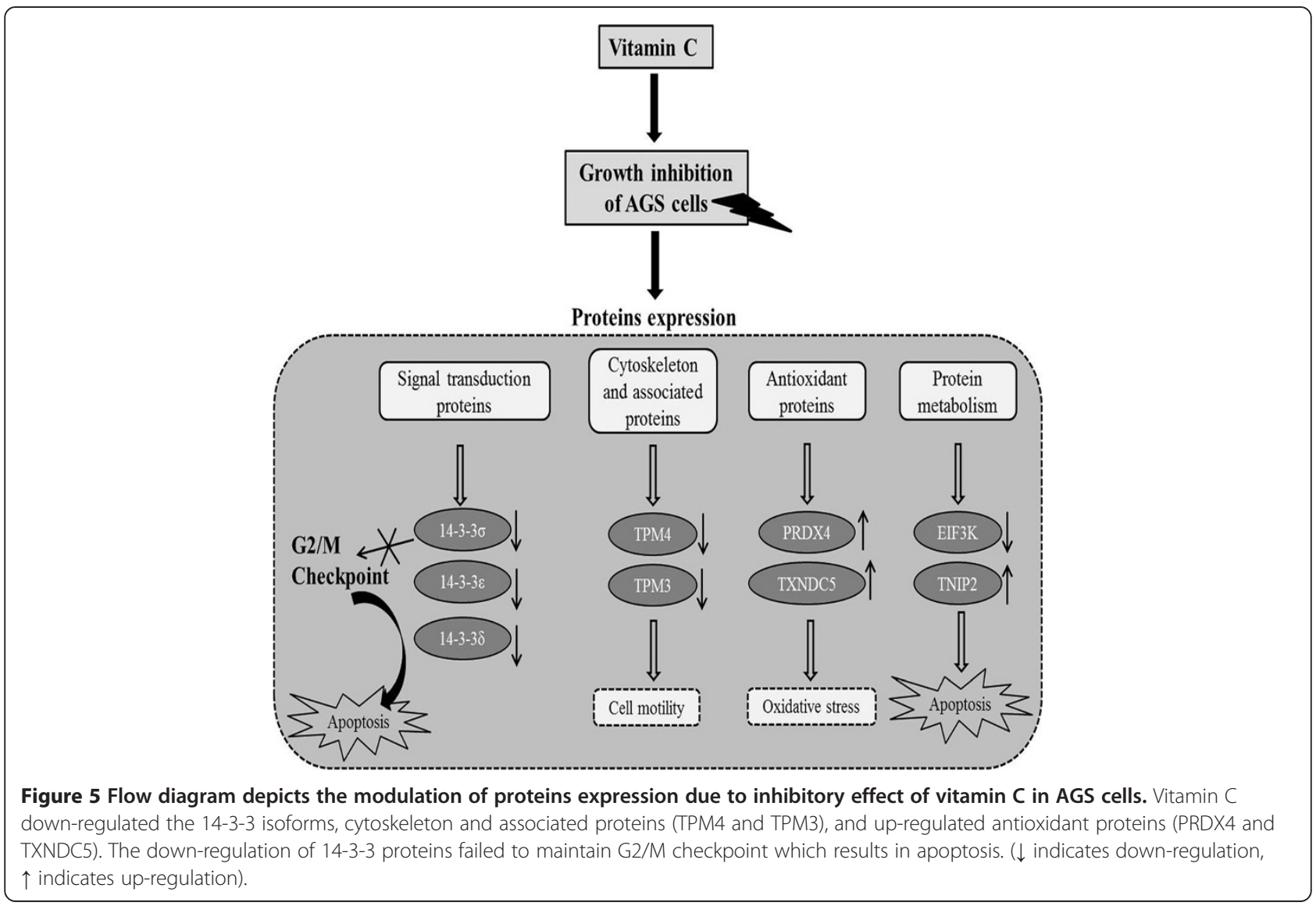




\section{Competing interests}

We declare that there are no conflicts of interests.

\section{Authors' contributions}

Conceived and designed the experiments: AN and GS-K; Performed the experiments: AN and HS-P; Analyzed the data: AN, HS-P and KI-P; Statistical analysis: JA-K, GE-H, SR-K and JZ; Wrote the manuscript: AN; Drafting and critical review of manuscript for important intellectual content: EH-K, WS-L and CK-W. All authors read and approved the final manuscript.

\section{Acknowledgements}

This work was supported by the National Research Foundation (NRF) of Korea Grant funded by the Korean government (MEST) (No. 2012045015) and the National R\&D Program for Cancer Control, Ministry for Health, Welfare and Family affairs, Republic of Korea (No. 0820050).

\section{Author details}

${ }^{1}$ Research Institute of Life Science and College of Veterinary Medicine, Gyeongsang National University, 900 Gajwadong, Jinju, Gyeongnam 660-701, Republic of Korea. ${ }^{2}$ Department of Biological Science, Center for Colon Cancer Research, University of South Carolina, Columbia, SC 29208, USA. ${ }^{3}$ Korea National Animal Research Resource Center, Korea National Animal Bio-resource Bank, Gyeongsang National University, Gazwa, Jinju 660-701, Republic of Korea. ${ }^{4}$ Department of Biological Enginneering, School of Natural Science, Kyonggi University, 14 Yeongtong, Suwon 443-760, Republic of Korea. ${ }^{5}$ Key Laboratory of Nuclear Medicine, Ministry of Health, Key Laboratory of Molecular Nuclear Medicine, Jiangsu Institute of Nuclear Medicine, Wuxi, Jiangsu 214063, China. ${ }^{6}$ Department of Nursing Science, International University of Korea, Jinju 660-759, Republic of Korea. ${ }^{7}$ Department of Internal Medicine, Institute of Health Sciences, Gyeongsang National University School of Medicine, Gyeongnam Regional Cancer Center, Gyeongsang National University Hospital, Jinju 660-702, Republic of Korea.

Received: 1 July 2013 Accepted: 24 September 2013

Published: 26 September 2013

\section{References}

1. Chiang AC, Massague J: Molecular basis of metastasis. N Engl J Med 2008, 359(26):2814-2823

2. Correa P, Malcom G, Schmidt B, Fontham E, Ruiz B, Bravo JC, Bravo LE, Zarama G, Realpe JL: Review article: Antioxidant micronutrients and gastric cancer. Aliment Pharmacol Ther 1998, 12(Suppl 1):73-82.

3. Steinmetz KA, Potter JD: Vegetables, fruit, and cancer prevention: a review. J Am Diet Assoc 1996, 96(10):1027-1039.

4. Ha YM, Park MK, Kim HJ, Seo HG, Lee JH, Chang KC: High concentrations of ascorbic acid induces apoptosis of human gastric cancer cell by p38MAP kinase-dependent up-regulation of transferrin receptor. Cancer Lett 2009, 277(1):48-54

5. Hong SW, Jin DH, Hahm ES, Yim SH, Lim JS, Kim KI, Yang Y, Lee SS, Kang JS, Lee WJ, Lee WK, Lee MS: Ascorbate (vitamin C) induces cell death through the apoptosis-inducing factor in human breast cancer cells. Oncol Rep 2007, 18(4):811-815.

6. Shin A, Kim J, Park S: Gastric cancer epidemiology in Korea. J Gastric Cancer 2011, 11(3):135-140.

7. Kelley JR, Duggan JM: Gastric cancer epidemiology and risk factors. J Clin Epidemiol 2003, 56(1):1-9.

8. Lee SA, Kang D, Shim KN, Choe JW, Hong WS, Choi H: Effect of diet and Helicobacter pylori infection to the risk of early gastric cancer. J Epidemiol 2003, 13(3):162-168.

9. Alaiya AA, Franzen B, Auer G, Linder S: Cancer proteomics: from identification of novel markers to creation of artifical learning models for tumor classification. Electrophoresis 2000, 21(6):1210-1217.

10. Sinha P, Poland J, Schnolzer M, Celis JE, Lage H: Characterization of the differential protein expression associated with thermoresistance in human gastric carcinoma cell lines. Electrophoresis 2001, 22(14):2990-3000.

11. Tomlinson AJ, Hincapie M, Morris GE, Chicz RM: Global proteome analysis of a human gastric carcinoma. Electrophoresis 2002, 23(18):3233-3240.

12. Ha GH, Lee SU, Kang DG, Ha NY, Kim SH, Kim J, Bae JM, Kim JW, Lee CW: Proteome analysis of human stomach tissue: separation of soluble proteins by two-dimensional polyacrylamide gel electrophoresis and identification by mass spectrometry. Electrophoresis 2002, 23(15):2513-2524.

13. Ryu JW, Kim HJ, Lee YS, Myong NH, Hwang CH, Lee GS, Yom HC: The proteomics approach to find biomarkers in gastric cancer. J Korean Med Sci 2003, 18(4):505-509

14. Nagappan A, Park KI, Park HS, Kim JA, Hong GE, Kang SR, Lee Do H, Kim EH, Lee WS, Won CK, Kim GS: Vitamin C induces apoptosis in AGS cells by down-regulation of 14-3-3sigma via a mitochondrial dependent pathway. Food Chem 2012, 135(3):1920-1928.

15. Swain M, Ross NW: A silver stain protocol for proteins yielding high resolution and transparent background in sodium dodecyl sulfatepolyacrylamide gels. Electrophoresis 1995, 16(6):948-951.

16. Shevchenko A, Wilm M, Vorm O, Mann M: Mass spectrometric sequencing of proteins silver-stained polyacrylamide gels. Anal Chem 1996, 68(5):850-858

17. Hahm E, Jin DH, Kang JS, Kim Yl, Hong SW, Lee SK, Kim HN, da Jung J, Kim JE, Shin DH, Hwang Yl, Kim YS, Hur DY, Yang Y, Cho D, Lee MS, Lee WJ: The molecular mechanisms of vitamin $C$ on cell cycle regulation in B16F10 murine melanoma. J Cell Biochem 2007, 102(4):1002-1010.

18. Kim H, Bae S, Yu Y, Kim Y, Kim HR, Hwang Yl, Kang JS, Lee WJ: The analysis of vitamin C concentration in organs of gulo(-/-) mice upon vitamin C withdrawal. Immune Netw 2012, 12(1):18-26.

19. Lin SY, Lai WW, Chou CC, Kuo HM, Li TM, Chung JG, Yang JH: Sodium ascorbate inhibits growth via the induction of cell cycle arrest and apoptosis in human malignant melanoma A375.S2 cells. Melanoma Res 2006, 16(6):509-519.

20. Chen Q, Espey MG, Krishna MC, Mitchell JB, Corpe CP, Buettner GR, Shacter E, Levine M: Pharmacologic ascorbic acid concentrations selectively kill cancer cells: action as a pro-drug to deliver hydrogen peroxide to tissues. Proc Natl Acad Sci U S A 2005, 102(38):13604-13609.

21. Thomas D, Guthridge M, Woodcock J, Lopez A: 14-3-3 Protein Signaling in Development and Growth Factor Responses. Curr Top Dev Biol 2005, 67:285-303

22. Yang X, Luo C, Cai J, Pierce WM, Tezel G: Phosphorylation-dependent interaction with 14-3-3 in the regulation of bad trafficking in retinal ganglion cells. Invest Ophthalmol Vis Sci 2008, 49(6):2483-2494.

23. Li WQ, Jiang Q, Khaled AR, Keller JR, Durum SK: Interleukin-7 inactivates the pro-apoptotic protein Bad promoting T cell survival. J Biol Chem 2004, 279(28):29160-29166

24. Zha J, Harada H, Yang E, Jockel J, Korsmeyer SJ: Serine phosphorylation of death agonist $B A D$ in response to survival factor results in binding to 14-3-3 not BCL-X(L). Cell 1996, 87(4):619-628.

25. Kim JE, Kang JS, Lee WJ: Vitamin C Induces Apoptosis in Human Colon Cancer Cell Line, HCT-8 Via the Modulation of Calcium Influx in Endoplasmic Reticulum and the Dissociation of Bad from 14-3-3beta. Immune Netw 2012, 12(5):189-195.

26. Ferguson AT, Evron $E$, Umbricht CB, Pandita TK, Chan TA, Hermeking $H_{\text {, }}$ Marks JR, Lambers AR, Futreal PA, Stampfer MR, Sukumar S: High frequency of hypermethylation at the 14-3-3 sigma locus leads to gene silencing in breast cancer. Proc Natl Acad Sci U S A 2000, 97(11):6049-6054.

27. Osada H, Tatematsu $Y$, Yatabe $Y$, Nakagawa $T$, Konishi H, Harano T, Tezel E, Takada M, Takahashi T: Frequent and histological type-specific inactivation of 14-3-3sigma in human lung cancers. Oncogene 2002, 21(15):2418-2424

28. Qi W, Liu X, Qiao D, Martinez JD: Isoform-specific expression of 14-3-3 proteins in human lung cancer tissues. Int J Cancer 2005, 113(3):359-363.

29. Samuel T, Weber HO, Rauch P, Verdoodt B, Eppel JT, McShea A, Hermeking $\mathrm{H}$, Funk JO: The G2/M regulator 14-3-3sigma prevents apoptosis through sequestration of Bax. J Biol Chem 2001, 276(48):45201-45206.

30. Qi W, Martinez JD: Reduction of 14-3-3 proteins correlates with increased sensitivity to killing of human lung cancer cells by ionizing radiation. Radiat Res 2003, 160(2):217-223.

31. Rodriguez Fernandez JL, Ben-Ze'ev A: Regulation of fibronectin, integrin and cytoskeleton expression in differentiating adipocytes: inhibition by extracellular matrix and polylysine. Differentiation 1989, 42(2):65-74.

32. Pittenger MF, Kazzaz JA, Helfman DM: Functional properties of non-muscle tropomyosin isoforms. Curr Opin Cell Biol 1994, 6(1):96-104.

33. Rhee SG, Woo HA, Kil IS, Bae SH: Peroxiredoxin functions as a peroxidase and a regulator and sensor of local peroxides. J Biol Chem 2012, 287(7):4403-4410.

34. Lin YM, Chen YR, Lin JR, Wang WJ, Inoko A, Inagaki M, Wu YC, Chen RH: elF3k regulates apoptosis in epithelial cells by releasing caspase 3 from keratin-containing inclusions. J Cell Sci 2008, 121(Pt 14):2382-2393. 
35. Vereecke L, Beyaert R, van Loo G: The ubiquitin-editing enzyme A20 (TNFAIP3) is a central regulator of immunopathology. Trends Immunol 2009, 30(8):383-391.

36. Kato M, Sanada M, Kato I, Sato Y, Takita J, Takeuchi K, Niwa A, Chen Y, Nakazaki K, Nomoto J, Asakura Y, Akatsuka M, Hayashi Y, Mori H, Igarashi T, Kurokawa M, Chiba S, Mori S, Ishikawa Y, Okamoto K, Tobinai K, Nakagama H, Nakahata T, Yoshino T, Kobayashi Y, Ogawa S: Frequent inactivation of A20 through gene mutation in B-cell lymphomas. Rinsho Ketsueki 2011, 52(6):313-319.

37. Compagno M, Lim WK, Grunn A, Nandula SV, Brahmachary M, Shen Q, Bertoni F, Ponzoni M, Scandurra M, Califano A, Bhagat G, Chadburn A, DallaFavera R, Pasqualucci L: Mutations of multiple genes cause deregulation of NF-kappaB in diffuse large B-cell lymphoma. Nature 2009 459(7247):717-721.

doi:10.1186/1471-2091-14-24

Cite this article as: Nagappan et al.: Proteomic analysis of differentially expressed proteins in vitamin C-treated AGS cells. BMC Biochemistry $201314: 24$

\section{Submit your next manuscript to BioMed Central and take full advantage of:}

- Convenient online submission

- Thorough peer review

- No space constraints or color figure charges

- Immediate publication on acceptance

- Inclusion in PubMed, CAS, Scopus and Google Scholar

- Research which is freely available for redistribution 